\title{
Inhibitors to the Electronic Teaching and Learning of Library Science in the Nigerian Universities of the Post-COVID-19 Pandemic Era and the Way Forward
}

\author{
Taiwo Adetoun Akinde \\ Faculty of Education Library, University of Ibadan, Ibadan, Nigeria \\ Email address: \\ taiakin2006@yahoo.com \\ To cite this article: \\ Taiwo Adetoun Akinde. Inhibitors to the Electronic Teaching and Learning of Library Science in the Nigerian Universities of the Post- \\ COVID-19 Pandemic Era and the Way Forward. American Journal of Information Science and Technology. Vol. 5, No. 2, 2021, pp. 30-39. \\ doi: 10.11648/j.ajist.20210502.13
}

Received: January 5, 2021; Accepted: March 9, 2021; Published: May 31, 2021

\begin{abstract}
This is a review of the extant literature on inhibitors to the electronic teaching and learning of Library and Information Science (LIS) in Nigerian universities. The university-wide inhibitors as identified by the study are non-provision or inadequacy of: funding, administrative and infrastructural supports, functional ICT laboratories/tools, ICT-compliant teaching staff and standby and responsive technical support for both teachers and students. Library schools' inhibitors include poor maintenance culture, lack of Internet presence, dedicated bandwidth and active websites while the teaching and learning inhibitors highlighted by the study are (older) teachers' poor attitude, concerns on how to retain the copyright of their lecture contents, plagiarism and the quality of students' work; fear of additional workload which may result in stress and burnt-out; lack of freedom or teaching autonomy (as teaching may now take the collaborations of colleagues, computer experts and instructional/graphic designers); teachers'/students' poor expertise and technology background and nature of course, among others. The author made suggestions on the way forward for an increased and a sustainable integration of ICTs in teaching and learning, especially in this Post-COVID-19 Pandemic Era where physical contact and interactions may need to be reduced to the barest minimum to contain contagious communication and consequent health hazards. This review has implications for library educators, students and educational managers in the universities of other developing countries.
\end{abstract}

Keywords: Electronic Teaching, E-learning, Library Educators, Library Schools, Nigerian Universities, Post COVID-19 Pandemic Era

\section{Introduction}

Electronic teaching and learning have to do with the deployment of information, communication and telecommunication technologies for instructional preparation, delivery and learning (in the real or virtual classroom). ICTs are positioned to aid universities, educators and students in the actualisation of objectives of teaching, learning and research through the provision of: (1) information materials needed for lecture preparation, teaching, learning and research and (2) technologies needed for the production, duplication, updating and delivery of lectures and learning content with ease. ICTs provide an array of tools and resources for acquiring, organising, communicating, producing, promoting, presenting and using ideas and information for teaching, reflecting, learning, decisionmaking, problem-solving, expressions and leisure. These tools and resources could also be used for cooperative learning and knowledge construction in the classroom while at the same time accessing a broader educational community and knowledge repositories beyond the walls of the classroom and school vicinity at any point in time. These technology experiences provide the skills that will enable educators and their students to perform effectively in the present global, digital, information-based and COVID-19 ridden world [15, 21, 30, 39].

From the extant literature reviewed for this study, four interlocking factors have been distinguished, which are: institution, educators, students and resources. Other frameworks addressing challenges to technology use in 
education highlighted similar critical factors going from school level factors to factors associated with the educators and students and to factors inherent in the pedagogy of teaching and learning with technology $[3,11,38]$.

Abdo \& Semela categorised these barriers into external and internal. Lack of equipment, unreliability of equipment, lack of technical support and other resource-related issues form the external barriers while school, educators and students factors such as beliefs about teaching, learning and technology were considered internal barriers in their research [1]. Furthermore, based on the prominent models of IT usage, a number of personal, behavioural, and environmental factors that have been found to influence educators' and students' use of technology for teaching and learning [4, 10, 22].

Akinde \& Adetimirin revealed the infrastructural facilities needed to support the use of educational support systems in the teaching and learning of LIS as lacking or inadequate in most of Nigerian universities [7]. According to the study, most of the administrators are not providing necessary technological leadership and encouragement in the use of educational support systems. Moreover, technical support in fixing configuration and installation issues, troubleshooting, repairs, provision of consumables, peripherals and other class supports while using ICT for teaching and learning are found not to be always adequate, hence, the slow, low or nonintegration of ICT for teaching and learning by library educators and students in university-based library schools in Nigeria. This has grave implication for LIS students' electronic learning possibilities.

This study reviewed the thoughts and/or opinions of experts and researchers and the author's observations, research and academic experience on the inhibiting factors to electronic teaching and learning (of LIS in particular) and what can be done to achieve an increased and/or a sustainable use of ICTs for teaching and learning of LIS in Nigerian universities, especially during endemic and national emergencies when schools may be closed as a precautionary measure. The major problem observed which may have implications for this Post COVID-19 Pandemic Era is the hitherto slow integration and low use of ICTs for teaching and learning in university-based library schools in Nigeria.

\subsection{Purpose of the Study}

This review, therefore, is an attempt at:

i. justifying the need for electronic teaching and learning of LIS in Nigerian universities to sustain teaching and learning at all times and especially during national pandemic and emergencies where access to the physical infrastructures in schools may be restricted;

ii. highlighting the inhibitors to the feasibility and sustainability of electronic teaching and learning of LIS;

iii. identifying the way forward as suggested by the literature and

iv. making recommendations.

The review has application for LIS students and educators in other developing countries and for faculty in countries seeking to expand their programmes and educational outreaches into the developing world at this point in history.

\subsection{Rationale for the Electronic Teaching and Learning of LIS in the Nigerian Universities of the Post COVID-19 Pandemic Era}

Universities in Nigeria are presently faced with many challenges. This can be seen in problems militating against excellent content delivery and management of courses as found in overcrowded lecture auditoriums as a result of inadequate infrastructure to cater for knowledge-craving young minds [6]. Such overcrowding however may predicate the quick communication of a contagious virus such as COVID-19. Justifying the need for technology integration in teaching and learning, studies have maintained that ICTs arrest students' attention, increase imagination and perception, improve understanding and aids the interactions of students and teachers $[12,15,40]$. It has also been asserted that with e-learning, students develop social skills and the capacity for initiative, creativity and responsibility $[25,26]$.

For a practical based course such as LIS, Akinde reported that some of the university-based library schools have no computer and/or ICT laboratories; some have out-dated laboratories with obsolete and not well maintained ICT equipment and tools while others with laboratories have no technical support [8]. Consequently, no gainful electronic or online teaching and learning can be done without a standard computer laboratory and well trained and responsive technical support staff on standby. Moreover, the library educators were found in the same study to be few (in comparison to student population) and overlaboured with the old fashioned oral or "chalk, board and talk" and "put pen on paper' models as the predominant methods of instructional delivery. This had hindered access to a whole world of open educational resources which electronic teaching and learning may afford.

Furthermore, an Internet-search for the library schools made by the author revealed that majority of them have no online presence and/or active websites; how then can they engage in electronic teaching and learning in this Post Convid-19 Pandemic Era where physical contact is being reduced to the barest minimum? where distance and/or remote teaching and learning is the new norm? Not to talk of bridging the present communication gap among the educators and between them and their students (the gap which has hitherto hinders national and international research collaborations, resource sharing, cooperative and/or collaborative teaching and learning and globalization of LIS programmes and curricular).

It is envisaged that the integration of holistic ICT infrastructure and tools into curricular content collection, development, delivery and management in these universities will minimise all the stated problems, if not eliminate them. It will also enable global competitiveness and a gainful and sustainable electronic or remote teaching and learning during pandemic, disasters, emergencies or whenever necessary. This is because the integration of ICT and electronic 
courseware will not only reduce physical contacts, it will also make up for the limited number of trained and experienced educators contending with teaching and managing a very high student population (for students and educators can be reached where they are).

When combined with robust staff training and development initiatives, electronic teaching and learning will lighten the educators' workloads, release quality time for research collaboration and enables easy updates to their lecture contents. It will also afford students the opportunities to study independently (at their place, time, rates and levels) and cooperatively (by joining learner groups), if need be. Providing individuality and yet collaboration $[5,12,15,33]$. It has been found that electronic teaching and learning save time, help in projecting the image of the institution, encourage knowledge advancement of staff and generally improve the quality of teaching and learning practices $[15,22]$.

Therefore, the successful introduction, further development and full deployment of electronic teaching and learning in university-based library schools in Nigeria may lead to ease of sourcing, populating, updating and managing of course content and learning materials; covering more 'grounds' in no time and making the delivery of course content and teaching/learning tasks easy and effortless and save the educators and their students the time, paper, transport and the physical contact that may encourage the spread of any epidemics.

However, in spite of reports of an increased number of computers installed in Nigerian universities' library schools, the literature reviewed revealed that computers are not extensively used for teaching purposes by library educators but for personal study and research. For instance, Akinde informed that, though computers have become widely used for administrative work (such as, preparation of lecture and unit plans, organising scores and reports of students and for official correspondence), entrance examinations and written interviews in some university-based library schools in Nigeria, this wide use has not been seen in the instructional activities of these library educators [6]. In most of the university-based library schools, it was found by the same author that individual educator's and student's initiatives rather than government and/or institutional initiative accounts for the few implementation and use of instructional technologies [8], hence the need to review extant literature to uncover factors inhibiting electronic teaching and learning.

\section{Inhibitors to Electronic Teaching and Learning in Universities: A Review of Literature}

The review done by this study revealed the following as factors inhibiting electronic teaching and learning in universities. For the purpose of discussion the author categorized them to three as follows: university-wide inhibitors, library schools' inhibitors and general teaching/learning inhibitors.

\subsection{The University-wide Inhibitors}

These are general problems affecting electronic teaching and learning in Nigerian universities which are not peculiar to the LIS departments. They are enumerated as follows:

\subsubsection{Inadequate Supply of Electric Power (Direct Source and Back-up) and Other ICT Infrastructure}

Past research studies on inhibitors to the use of technology for teaching in Nigerian tertiary education have found the main inhibiting factor to be the insufficient electric power supply $[21,28,34]$. It was revealed that the major inhibitor to classroom technology implementation and ICT use in higher educational system in Nigeria is the epileptic or inconsistent electric power generation and supply and the unbearably costly service (which may run to millions of naira in a month) of the electricity distributing companies which most of the ICT infrastructures are dependent on. Most universities in Nigeria lack electrical power backup in form of inverters and solar powered systems (which can convert and conserve electrical power) and power generating set or plants. Fortunes are often used to maintain some institutional power plants in terms of repair and fuel. Talking of electronic teaching and learning of LIS therefore, little or nothing can be done without a consistent and regular power supply and other ICT infrastructure [8].

\subsubsection{Inadequate Funding}

Another inhibitor according to literature is funding. It was found that the overall educational system in Nigeria is underfunded and that available funds are used by tertiary institutions to solve more urgent and important survival needs [7, 9, 22, 36]. The development and subsequent operation of ICT require huge financial investment in, and commitment to, the acquisition of necessary facilities and their utilisation and maintenance, hence, the need for finance can never be over-emphasised.

Nonetheless, Ofuyatan, Opaluwa \& Adeola advised that if the government money is not forthcoming, higher institutions managements in Nigeria should collaborate with the private sector to seek alternative funding sources for capacity development of electronic educational initiatives [37]. Money answereth all things, goes the Holy Bible. Funding, therefore, remains a major constraint in most of the electronic teaching and learning initiatives' implementations. Though, opportunities for sponsorship may not be scarce in some cases but some of the sponsors may require stringent terms and conditions which most of the universities may not be able to meet.

\subsubsection{Lack or Inadequate Administrative Support}

An inhibiting factor found during this review is inadequate administrative support. These authors revealed that the attitude and support of leaders in and outside Nigerian institutions towards the development and use of ICT related facilities was either slow, poor or nil [6, 7, 21, 28]. According to Eze, Chinedu-Eze, Okike \& Bello, abysmal management commitment to interactive knowledge environment is the 
bane of electronic teaching and learning. However, taking a broader look, they insisted that the problem is related not only to the lack of political will on the part of government but courage on the part of educational policy makers and institutional heads to fully integrate technology into teaching and learning and tackle any challenges arising thereby [22].

The author asserted (from her observations as an academic staff of university for almost twenty years) that most of the university administrators show apathy to, lack interest in or at best pay lip service to the electronic teaching and learning of courses either because it was not included in their own trainings, its complexity as a result of various technicalities and logistics involved in its implementations and the huge fund required in acquiring ICT infrastructure. Though, funds are always limited yet the limited fund provided and/or generated is sometimes misappropriated by administrators as a result of greed and absence of checks and balances in the system.

\subsubsection{Lack of (or Poor) Expertise, Requisite Training and Training Sponsorship}

Previous studies found lack of expertise and requisite training as inhibitors to electronic teaching and learning [18, 25, 27, 30, 42]. They affirmed that many educators and students in higher education institutions of learning lack adequate ICT skills, experience and background that will make them effective in their jobs and study in this digital age. Similarly, it was gathered that most institutions of higher learning in Nigeria lack: adequate training facilities for ICT education; computer literate teachers and ICT experts who would support and manage available systems [22, 28, 38]. The authors stressed that most teachers and students lack training and retraining on how and when to apply the various technology-enabled pedagogical and learning strategies and applications available in order to harness the great educational advantage and opportunities ICTs offer.

This assertion was further corroborated by Asiyai who averred that most higher education institutions in Nigeria lack vibrant staff development programmes [13] while Ofuyatan, et al. revealed that most of them are still at low level of ICT integration due to inadequate skilled hands, staff, sufficiently trained to develop, operate/use and maintain ICT-enabled educational tools and equipment [37].

However, the excuse of the administrators for this training deficit and the consequent poor exposure of teachers and students to technology integration in teaching and learning has always been lack of fund for sponsorship to required trainings.

\subsection{Library Schools' Inhibitors}

These are inhibitors that were found in some of the LIS departments according to the literature and author's observation and visitations for data collection for a doctoral thesis. They are listed thus:

\subsubsection{Lack of Dedicated Bandwidth Resulting in Slow Speed and Unstable Internet Connectivity}

Identifying thin Internet bandwidth and unstable connectivity as inhibitors, literature affirmed that, Nigeria, like most developing nation faces constraint such as thinbandwidth which may hamper fruitful literature search, upload and download necessary for electronic teaching and learning [2, 6, 20, 36]. According to these studies, the country lacks adequate broadband network which could seamlessly aids ICT operations. Ekundayo \& Ekundayo showed that almost $60 \%$ of African countries have bandwidth that is less than that of a typical institution in the developed world and added that only six countries in Africa have a reasonable outgoing bandwidth. They informed that Internet connectivity is usually available in most tertiary institutions in Nigeria but in most cases the bandwidth subscribed to (which determines speed of access) is too small to support any meaningful academic activity during peak periods, thereby making the promise and prospects of teaching and learning with technology at these periods, bleak [20].

An Internet-search for the university-based library schools made by the author revealed that majority of them have no online presence and/or active websites not to talk of dedicated Internet bandwidth.

The author opined that LIS students and staff who are not resident in their university campuses, especially those living in urban city (with the propensity for high Internet traffic jam) and remote villages (with insignificant signals), may not be able to access a stable Internet connectivity and consequently might only make do with the access provided by their departments/institutions and/or commercial cybercafes for resources needed for their research reports and other academic projects. Hence, the need for a dedicated bandwidth necessary for a robust Internet access in the university-based LIS schools can never be over stressed.

In addition, the author maintained that most staff and students of higher institution of learning in Nigeria may not be able to personally afford an outgoing and sustainable Internet access because of their meager salary and poor standard of living. This may explain the incessant staff strikes, student riots and other clamours for upward review of salaries, conditions of service and enabling teaching and learning environments necessary for best practices and global competitiveness in these institutions. A concern expressed in the study of Asiyai on the challenges of quality in the Nigerian higher education of the $21^{\text {st }}$ century [13]. Related to the argument on affordability of Internet access is the study of Assareh, Bidokht \& Hosseini which found that students and teachers lack access to computing facilities at home and restricted access at school [15].

\subsubsection{Lack of or Inadequate Departmental Technical Support}

According to the submission of the library educators in the unpublished thesis of Akinde, inadequate and non-provision of functional ICT laboratories, standard accommodation for ICT tools and technical support for both teachers and students in the university-based library schools are major constraints to ICT integration in teaching and learning of LIS. Others, according to her, are problems arising from: 
compatibility issues as a result of obsolete systems and tools; Learning Management Software (LMS) local development or outright purchase; patent registration and courseware counterfeiting and license expiration, updating and renewal, issues the LIS department may not be able to easily fix for want of technical expertise [6].

From the author's experience while gathering data for a $\mathrm{PhD}$ thesis, most of the LIS departments had no full-time technical support personnel. Some were tapping from the university-wide support which was marginal at best while others engaged the services of ICT contractors and computer engineers from the Private Sector.

Similarly, Ghavifekr, \& Rosdy found in their study on teaching and learning with technology that most computer laboratories and tools were not always in good condition and neither were the teachers given adequate support [26].

\subsubsection{Lack of Internet Presence and Active Website/Blogsite}

An Internet-search for the university-based library schools made by the author as stated earlier revealed that majority of them have no online presence and/or active websites other than the institutional websites which may have restricted access and electronic accommodation (storage) for departments due to servers and broadband capacity. No institutional Website can fully and satisfactorily serve all departments, little wonder the present electronic teaching and learning deficit and backwardness observed in some of these schools.

According to the author, LIS departments' Internet presence and active Websites will enable and enhance:

i. access to a whole gamut of electronic repositories and a larger electronic/cloud storage capacity (for instance, on Google drive, Dropbox and institutional server/emails);

ii. richer interactions and more opportunities and exposures to many teaching and learning tools which are hitherto not accessible and/or affordable;

iii. currency. Being in the know of current research and academic, social and political developments at local, national and international levels;

iv. visibility and hence, opportunity for collaboration, exchange programmes, sponsorship, grant and scholarships to foreign academic events and the consequent internationalization and standardization of curricular [30]

The author sees missing all these opportunities, as a department, through lack of Internet presence and active Websites as missing a lot!

\subsubsection{Poor Maintenance Culture}

From the author's observation, most of the ICT tools acquired in Nigerian library schools are left to rot, rust and wear away for want of expert care, attention and maintenance. Most times, they are left to the mercy of the cleaners and untrained who mishandle them at will as a result of lack of or inadequate training, ignorance of the proper way of handling and professional procedures for regular maintenance. Besides, most of the manuals and guides that accompanied the ICT tools and equipment are mostly put aside and may never be consulted again after initial successful installations.

With this poor maintenance culture, most hardware pack up or enter state of disrepair in no time. When this happens, they are immediately auctioned out and the money generated used for other pressing needs at best or misappropriated if the head of the department lack integrity.

Moreover, faulty computers and tools are sometimes left in the Network which may increase the incidences of hangings and downtimes. Isabirye \& Dlodio advised the identification, removal and/or repair of such [30].

\subsection{Other Teaching and Learning Inhibitors}

Other teaching and learning inhibitors gathered from the review of the literature are as follows:

\subsubsection{Virus Attack and Privacy/Security Concerns}

Electronic data/information stored in computer files and internal hard drives are sometimes lost to software virus infestations, information theft and the unwholesome activities of hackers $[6,26]$. This may explain the reluctance of some LIS teachers and students to use online platforms which is required for electronic teaching and learning.

\subsubsection{Teachers' Lack of Inertia or Loss of Interest and Apathy}

This may be due to: i. teachers not being carried along by the university management in previewing and developing elearning initiatives and ii. the capacity for administrative monitoring inherent in teaching and learning management systems $[6,30]$. Hence, LIS teachers, among others, may not be willing to subscribe to electronic teaching and learning: $i$. if they are not involved in planning prior to implementations and ii. if they know that the electronic teaching initiative has automatic back-up systems for clocking, audio recording and video coverage which may easily uncover malpractices such as truancy, lateness, absence, poor lecture content, plagiarized lesson notes, poor pedagogical skill, among others.

\subsubsection{Lack of Students'Support, Capacity, Confidence, Familiarity and Adjustment}

Students are important stakeholder in the deployment and use of any electronic teaching and learning initiative. Nothing much could be achieved by teachers with regard to electronic teaching without students' support, knowledge, ability and self-efficacy in the gainful use of electronic learning management systems $[6,15,21]$. Moreover, electronic teaching and learning affords a more diverse learner group (especially in distance learning), whose varying interests the university management may need to take into consideration in policy making on and implementations of electronic teaching and learning practices/initiatives. Hence, without students' adjustments and active involvement, no electronic learning of LIS can take place regardless of the quantity of electronic teaching university managements could 
enforce! Therefore, the onus lies with the management to seasonally organize training for students with regards to electronic learning and evaluate or assess the learning impacts of online/electronic teaching from the LIS students' perspectives.

\subsection{4. (Older) Teachers' Belief About Technology Use in Teaching and Learning}

Literature revealed that some teachers especially the older ones have negative belief about the usefulness of technology in teaching and learning due to the fact that they may lack technology background and may not see reasons why they should integrate it now; hence, their poor attitude to technological change and innovation in classroom/education $[8,15,23,26,30]$. This should be noted for awareness and re-orientation campaigns and training needs of teachers in the gainful deployment of electronic teaching and learning in university-based library schools in Nigeria.

\subsubsection{Concerns About Copyright, Plagiarism, Quality of Students' Work, Sabotage from Peers and Additional Workload}

Teachers' concerns on how to retain the copyright of their original lesson contents, plagiarism of their works if uploaded, their being accused of plagiarism if they upload the contents they get from different online sources and the poor quality of their students' work, students, who may now have access to a whole gamut of online information to copy from without any filter. Furthermore, teachers may fear likely sabotage from peers and additional workload arising from the preparation and delivery of the online classes which may need to be made 'perfect' now because of their being in the public domain as soon as they are delivered. This new strain may result in stress and burnt-outs $[10,18,30,31]$. These concerns have been found to be true for all teachers involved in electronic teaching, including LIS teachers.

\subsubsection{Lack of Teaching Autonomy}

Electronic teaching and learning may cause lack of freedom or teaching autonomy as teaching may now take the collaborations of colleagues, computer experts, editors, producers and instructional/graphic designers [11, 5, 30]. This goes without the saying that LIS teachers, among others, may not like to be stripped of their autonomy and authority in their subject classroom, an environment which has been their main reserve hitherto. This disposition may however inhibit the deployment and further development of electronic teaching and learning practices.

\subsubsection{The Inefficiency of Technical Support Personnel}

The inefficiency of some technical support personnel in offering assistance during the instructional preparation and delivery/learning activities of teachers and students they are engaged to assist is a constraint to electronic teaching and learning [8]. Some technical support personnel, though paper-qualified, may lack pedagogical skills and the knowledge of how to apply their technical skills to teaching and learning environments in order to justify their appointments. Consequently, the need for engaging and organizing seasonal training for technical support staff in Nigerian university-based LIS schools can never be overemphasised.

\subsubsection{Restricted Access to Electronic Teaching and Learning Facilities}

As a result of institutional/departmental policy, culture and time scheduling, some teachers and students may be restricted from accessing some teaching and learning facilities outside their teaching/learning time schedules [12, $22,26]$. This may reduce self-teaching and development and increase resistance of LIS teachers and students to electronic teaching and learning initiative. Yes, LIS teachers and students need personal time with teaching/learning technology devices and/or facilities to increase familiarity and enhance self-efficacy.

\subsubsection{Nature of Course (Whether Practical Oriented or Theoretical)}

Practical-oriented courses have been found to lend themselves to technology integration in teaching and learning. Hence, any university willing to embrace electronic/online education may need to appoint Faculty/departmental representatives who will relate discipline specific concerns and experts' advice to the learning management systems' administrators/team for the purpose of customization/profiling during hardware and software installations and for the training and retraining of staff and students in the particular subject/discipline adaptation of technology thereafter [30]. The author believes that LIS as a practical oriented course will lend itself to technology integration, if only the LIS teachers could lead the way.

\section{On the Way Forward}

The following are the solutions proffered by the extant literature to the inhibitors listed above:

\subsection{Adequate Funding and Facilities}

Past research studies suggested adequate funding of ICTdriven initiatives by government; revenue generation drives by individual institutions and the creation of sound policy environment which will encourage investment in ICT and draw the private sector into ICT development [28, 31, 37, among others]. They further advised that institutional governors and educational policy makers should work with the private sector (for instance, telecommunication companies (e.g. MTN Nigeria); banks and other well established enterprises); international funding agencies (for example, Carnegie Corporation of New York; CARTA, Ford and Rockefeller Foundations, to enumerate a few) and the civil society to ensure affordable and sustainable access to ICT infrastructure.

Akinde advised the release of the proposed University Needs Assessment Fund as demanded by the Academic Staff 
Union of Universities (ASUU) from the Federal Government of Nigeria and loan to educators and students to procure personal ICTs [6].

Furthermore, Ilaonusi \& Osuagwu proffered that the financial assistance of government departments (for instance, Nigerian Communications Commission (NCC), Education Trust Funds (ETF), Tertiary Education Tax Fund (TETFund) and Petroleum Development Tax Fund (PDTF)) could also be sought by university managements. With adequate funding by government, international bodies and the private sector including Non-Governmental Organisations (NGOs), they believed there would be adequate provision of the required ICT infrastructure, facilities and courseware for effective academic globalisation and research productivity [29].

\subsection{Regular Training, Retraining, Technical Support and Self-development}

Many studies proffered the need to sponsor new teachers and students to intensive and massive training in the rudiments of electronic teaching and learning; old teachers and students to retraining/refresher programmes in different ways of engaging ICT in education and the deployment of ICT-compliant and skilled manpower (teaching and support staff) in order to increase access to electronic educational opportunities [21, 27, 33-36]. On their part, Ofuyatan, et al. advised that long-term professional development which will lead to local manufacturing of ICT hardware and the development of in-house software for Computer Aided Instruction (CAI) and Learning Management System (LMS) should be encouraged to reduce the cost of acquiring the software and hardware components [37].

However, while Asongu \& Le Roux and Guri-Rosenblit proposed official provision of resources and reduction in teaching workload to allow time for self-teaching, especially after training [14, 27], Akinde opined that where official support is not forthcoming individuals should also strive to invest in their self-development as this will make them to be not only professionally competent but marketable, proactive and a step-ahead in their career [6].

\subsection{Provision of Adequate ICT Infrastructure and Tools, Technology Transfer and Knowledge Sharing}

In the unpublished work of Akinde, she advised the provision of the right/compatible, new and/or modern ICTs, accessibility to and maintenance of available ones; adequate and alternative electric power sources and backups; dedicated and adequate bandwidth and stable and reliable Internet connections [6]. Isabirye \& Dlodio proffered commensurate bandwidth to the number of staff and students requiring access to prevent server overload and the subsequent crash which may cost a lot of money and time to restore [30] while Nwokolo, Aliu \& Rabiu recommended that government and institutions should invest in alternative and renewable energy sources (for example, inverter, solar, biofuel, among others) for a sustainable power supply [36].

In addition, Abubakar suggested that technology transfer, knowledge sharing, peer tutoring and teamwork among teachers and students are necessary for gainful and sustainable electronic teaching and learning of LIS in Nigerian universities [3].

\subsection{Collaboration and Cooperation of All Stakeholders}

For a profitable use of ICT in teaching and learning, some studies proffered the encouragement of collaboration of universities with technology companies and cooperation among departments offering similar courses across Nigerian universities in designing and developing rich materials and courseware for online education [30, 31, 41]. Moreover, Akinde suggested that the university managements should be educated on the importance of ICT integration in teaching and learning and their purposive support in drafting policy statements on ICT provision, use, time of use, incentives to encourage use (such as certification, promotion, recognition, among others), trainings and its regularity, maintenance and its frequency and what percentage of the budget to be allocated. She recommended that the use of ICTs should be made mandatory for LIS education and practice [6].

\section{Conclusion and Recommendations}

\subsection{Conclusion}

Haven justified the need for the electronic teaching and learning of LIS, discussed three categories of inhibitors and highlighted the way forward according to the literature, author's observation and experience, the author concluded that to encourage library educators' and their students' seamless transition to electronic teaching and learning environment and to enhance teaching/learning quality and effectiveness, especially in this post COVID-19 pandemic era where physical contact need to be restricted to the barest minimum, all hands should be on deck to provide the infrastructures, resources and supports enumerated and discussed above, the lack of which was found to be inhibiting electronic teaching and learning in university-based library schools in Nigeria.

It is important to note that the literature from developed countries on some of these inhibitors are scanty because many of these countries (and educators) have passed these thresholds and overcame some of these challenges. Which means overcoming these inhibitors is a possibility, therefore, library educators and students in Nigerian universities could do better in exploring and benefitting from the massive educational opportunities and resources inherent in electronic teaching and learning given a purposive and adequate administrative, financial, infrastructural and technical supports at every given time.

\subsection{Recommendations}

From the foregoing discussion and conclusion, the author recommends as follows:

\subsubsection{Regular and Consistent Lobbying and Advocacy}

Governments' and university administrators' efforts at 
giving the LIS educators and their students all the needed supports could facilitate increased use of electronic teaching and learning among them leading to quality and effective teaching practices, better working and learning environments and richer learning experiences for LIS students. Therefore, advocating and lobbying for adequate financial supports from governments, private sectors, alumni associations and networks, intergovernmental organisations (for instance, UNESCO and UNICEF, among others) and Foundations that believe in educational technological advancement such as Bill and Melinda Gate and McArthur, cannot be overemphasised, especially at this time in the history of the world when we are just recovering from the economic devastation caused by the COVID-19 Pandemic.

\subsubsection{Standby and Responsive Technical and Financial Support}

Standard laboratory, adequate and technologically compliant, qualified, responsive and full-time technical support personnel and sufficient and functional ICT infrastructure should be established and/or provided to promote LIS educators' and students' seamless and successful use of electronic teaching and learning platforms in the university-based library schools in Nigeria. In addition, students and teachers should be supported to acquire and use own devices as this will encourage self-teaching and development. Gifts of personal computers and data credits (air time) to students and academic staff of higher institutions of learning to access Internet whenever and wherever may not be out of place.

For a sustainable support however, LIS department should employ at least two technicians and/or engineers who will be giving unrelenting professional services (in form of training, consultation and ware-care) to its staff, students and department besides the offers of technical support from the university.

\subsubsection{Active Website, Online Engagements in Academic and Social Groups and Dedicated Bandwidth}

For a larger cloud space and wider electronic interactions, LIS departments may need to own and maintain a Web/Blog site (apart from their institutions' Websites) to enable worldwide visibility, attract research collaboration, access Open Educational Resources (OERs) and certifiable Massive Open Online Courses (MOOCs) for staff and students from anywhere in the world. With departmental Website therefore, electronic teaching and learning of LIS for regular learners and the commercialisation and liberalisation of education through distance learning are possibilities.

In addition, opening and maintaining academic and social networking media accounts and creating learning, professional and social groups and/or e-laboratories on Academia.edu, ResearchGate, LinkedIn, Twitter, WhatsApp, Facebook, among others, for added visibility and advantage, would be a game-changer. Where fund could be mobilised, a dedicated bandwidth is advised for each of the universitybased library schools for faster and sustainable Internet access.

\subsubsection{Adequate Time to Be Scheduled for Electronic Teaching and Learning Encounters}

The author observed that the one hour allocated for each subject in the ongoing Emergency Remote Teaching (ERT) of the University of Ibadan, an instance of electronic teaching and learning implemented in the first semester of the $2020 / 2021$ academic session as a measure to contain the spread of COVID-19, was sometimes insufficient for any meaningful synchronous learning and gainful discussion to take place. In other words, students will not be able to gain much from online contacts with subject teachers if time is not allowed for initial connection, failures and settlement.

Consequently, the time to be scheduled for electronic teaching and learning should allow for booting, technical failures and possible shutdowns. Otherwise, little or nothing will be taught or learnt when faced with any hardware or courseware failure. A minimum of two-hour teaching time in a day and two contacts in a week is therefore recommended for each subject to allow for possible troubleshooting which may arise from likely system failure, the processing necessary for resolutions and time needed to update/revise previous lesson (notes). After all, with technology, teaching and learning now liberalized could take place at any time in the 24 hours of the day.

\subsubsection{Electronic/Online Education Curricular Standardization and Quality Assurance}

Based on the diverse inhibitors highlighted by various studies in the literature reviewed, it is suggested that some benchmarking and standardisation of the basic components and requirements for the electronic/online/distance teaching and learning of LIS at the university level may need to be done by the National University Commission (NUC), the Nigeria Library Association (NLA), the Librarians Registration Council of Nigeria (LRCN), Heads of university-based library schools, Committees of Vicechancellors and other educational policy makers to assure quality and diminish inequities in learning experiences and achievements for Nigerian university LIS students who are all going to compete for the same job in the national (if not global) labour market after their graduation.

\subsubsection{Suggestions for Further Studies}

This review scenario is that of undergraduate teaching and learning environments, further studies could be carried out to find out whether there are significant differences between the inhibiting factors to the electronic teaching and learning of LIS at undergraduate and postgraduate levels; given that graduate students are more socially mature and can attract grants to their universities. Besides, their economic and financial maturity afford them the ability to acquire own learning devices while their likely technological competence as a result of their level of study, research and work experience may make them more adept at any electronic learning endeavour. There is no postgraduate university in the country as at date, though, University of Ibadan is tending towards being one as a result of its place, age, history, its state of the art College of Postgraduate Studies, Business 
School and massive applications for admission receive every year from students around the world.

\section{References}

[1] Abdo, M. and Semela, T. (2010). Teachers of poor communities: the tale of instructional media use in primary schools of Gedeo Zone, Southern Ethiopia. Australian Journal of Teacher Education 35 (7), 78-92.

[2] Abdulhamid, T. H., Shafiu, M. T. and Murtala, A. (2017). Perpetuation intention of using e-learning among universities students in Nigeria. International Journal of Science and Technology Management 6 (5), 28-41.

[3] Abubakar, B. M. (2014). Rethinking e-learning in library and information science (LIS) education in Nigeria: developing a model for the 21st century. Information and Knowledge Management 4 (9), 68 -76. Retrieved 1 Feb, 2016, from www.iiste.org.

[4] Akinde, T. A. (2016a). Theoretical modelling to explain library educators' use of Educational Support Systems in university-based library schools in Nigeria: Extending the Technology Acceptance Model (TAM). Library Philosophy and Practice Paper 1416, 24pp. (Available online at $\mathrm{http}: / /$ digitalcommons.unl.edu/libphilprac/1416/) United States of America

[5] Akinde, T. A. (2016b). Types and use of Educational Support Systems by library educators in universities in Nigeria: Towards quality and effective teaching practices. Published by the Academic Research Journals in International Journal of Academic Library and Information Science Vol. 4, No. 6: 158171, DOI: 10.14662/IJALIS2016.033 (Available online at http://www.academicresearchjournals.org/IJALIS/Content/201 6/July/Content.htm).

[6] Akinde, T. A. (2017). Influence of attitude, perception of use and institutional support indices on integration of Information and Communications Technologies in teaching by the library educators in Nigerian universities. An unpublished $\mathrm{PhD}$ thesis of the Faculty of Education, University of Ibadan, Nigeria.

[7] Akinde, T. A. and Adetimirin, A. E. (2019). Administrative and infrastructural factors affecting library and information science educators' actual use of educational support systems for teaching in Nigerian universities. Journal of Librarianship and Information Science Vol. 51, No. 1, 180-195. Available online at http://www.journals.sagepub.com/home/lis DOI: 10.1177/0961000618773140. Published by SAGE, United Kingdom.

[8] Akinde, T. A. (2020). Use of instructional technologies in Library and Information Science Schools in Nigerian Universities: Raising the bar in pedagogical content delivery. International Journal of Library and Information Science Studies Vol. 6, No 1, Pp. 12 - 37. European American Journals of the European Centre for Research Training and Development (ECRTD), United Kingdom.

[9] Alexander, B., Adams-Becker S., Cummins, M. and HallGiesinger, C. (2017). Digital literacy in Higher Education Part 1: An NMC Herizon Project Strategic Brief. Vol. 3\&4, August 2017. Austin, Texas: The New Media Consortium.

[10] Al-Gahtani, S. S. (2016). Empirical investigation of e-learning acceptance and assimilation: a structural equation model. Applications and Computer Information 12 (1), 27-50.

[11] Andrade, M. S. (2015). Effective e-learning and e-teaching: a theoretical model. In B. Gradinarova (ed). E-learning: Instructional Design, Organisational Strategy and Management in Technology. Doi: 10.5772/60578.

[12] Arghya, R., Pradip, K. B. and Shilpee, A. D. (2020). Psychological analytics based technology adoption model for effective educational marketing. In digital and social media marketing: emerging applications and theoretical development. Switzerland: Springer.

[13] Asiyai, R. I. (2013). Challenges of quality in higher education in Nigeria in the $21^{\text {st }}$ Century. International Journal of Educational Planning \& Administration 3 (2), 159-172 (http://www.ripublication.com/ijepa.htm).

[14] Asongu, S. A. and Le Roux, S. (2017). Enhancing ICT for inclusive human development in Sub-Saharan Africa. Technical Forecast and Social Change 118 (C), 44-54.

[15] Assareh, A. Bidokht, M. and HosseinI. (2011). WCIT 2010: Barriers to e-teaching and e-learning. Procedia Computer Science 3, 791-795. Available online at www.sciencedirect.com.

[16] Chien, S. P., Wu, K. H. and Hsu, Y. S. (2014). An investigation of teachers' beliefs and their use of technology based assessments. Computers in Human Behaviour 31, 198-210.

[17] Ciechanowski, L., Przegalinska, A., Magnuski, M. and Gloor, P. (2019). In the shades of the uncanny valley: an experimental study of human-chatbot interaction. Future Generation Computer Systems 92, 539-548.

[18] Cook, R. G., Ley, K., Crawford, C. and Warner, A. (2010). Motivators and inhibitors for university faculty in distance and e-learning. British Journal of Educational Technology, Spring, 2010 .

[19] Edegbo, W. O. (2011). Curriculum development in library and information science education in Nigerian universities: issues and prospects. Library Philosophy and Practice 2011. Retrieved Feb 1, 2016, from http://unllib.unl.edu/LPP/

[20] Ekundayo, M. S. and Ekundayo, J. M. (2009). Capacity constraints in developing countries: a need for more e-learning space? the case of Nigeria. Paper proceedings held at ASCILITE, Auckland. 243-255.

[21] Eze, S. C., Chinedu-Eze, V. and Bello, A. O. (2018). The utilization of e-learning facilities in the educational delivery system of Nigeria: A study of M-University. International Journal of Educational Technology in Higher Education 15(34), 1-20 (https://doi.org/10.1186/s41239-018-016-2).

[22] Eze, S. C., Chinedu-Eze, V. C. A., Okike C. K. and Bello, A. O. (2020). Factors influencing the use of e-learning facilities by students in a private Higher Education Institution in a developing economy. Humanities \& Social Sciences Communications 7: 133, 1-15 (http://doi.org/10.1057/s41599020-00624-6).

[23] Franco, M. and Garcia, M. (2018). Drivers of ICT acceptance and implementation in micro-firms in the estate agent sector: influence on organizational performance. Information Technology Development 24 (4), 658-680. 
[24] Gbaje, E. S. and Kotso, J. A. (2011). Entrepreneurship in library and information works: opportunities and challenges. Paper presented at the Bi-annual conference of the National Association of Library and Information Science Educators (NALISE) held at Ahmadu Bello University, Zaria, Nigeria, 8th-12th November, 2011.

[25] Ghavifekr, S., AbdRazak, A. Z., Ghani, M. F. A., Ran, N. Y., Miexi, Y. and Tengggyue, Z. (2014). ICT integration in education: Incorporation for teaching and learning improvement. Malaysian Online Journal of Educational Technology (MOJET) 2 (2), 24-46.

[26] Ghavifekr, S. and Rosdy, W. A. W. (2015). Teaching and learning with technology: Effectiveness of ICT integration in schools. International Journal of Research in Education and Science (IJRES) 1 (2), 175-191.

[27] Guri-Rosenblit, S. (2018). E-teaching in higher education: An essential pre-requisite for e-learning. Journal of New Approaches in Educational Research 7 (2), 93-97. Doi: 10.7821/naer.2018.7.298.

[28] Idowu, A. I. and Esere, M. (2013). ICT and higher educational system in Nigeria. Educational Research and Reviews 8 (21), 2021-2025. Retrieved Feb 1, 2016, from http://www.academicjournals.org/ERR

[29] Ilaonusi, N. O. and Osuagwu, C. C. (2009). ICT in education: achievements so far in Nigeria. Research, Reflections and Innovations in Integrating ICT in Education. 1331-1335.

[30] Isabirye, A. K. and Dlodio, N. (2014). Perceived inhibitors of innovative e-learning teaching practice at a South African University of Technology. Mediterranean Journal of Social Sciences 5 (4). Rome, Italy: MCSER Publishing. Doi: $10.5901 / \mathrm{mjss} .2014 \mathrm{v} 5 \mathrm{n} 4 \mathrm{p} 390$.

[31] Lane, A. (2017). Business models for OER and MOOCs beyond monetary incentives. In G. Ubachs, L. Konings \& M. Brown (eds). The Envisioning Report for Empowering Universities (Pp. 13-15), Maastricht, NL: EADTU.

[32] Napitupulu, D., Syafrullah, M., Rahim, R., Abdullah, D. and Setiawan, M. I. (2018). Analysis of user readiness towards ICT usage at small/medium enterprises in South Tangerang. Journal of Physics 1007(1), https//doi.org/10.1088/1742$6596 / 1007 / 1 / 012042$

[33] Nuryyev, G., Wang, Y. P., Achyldurdyyeva, J., Jaw, B. S., Yeh, Y. S. Lin, H. T. and Wu, L. F. (2020). Blockchain technology adoption behaviour and $\mathrm{s}$ : ustainability of the business in tourism and hospitality SMEs: an empirical study. $\begin{array}{llll}\text { Sustainability } & 12 & \text { (3), } & 12-56\end{array}$ (https://doi.org/10.3390/su/2031256.

[34] Nwana, S. (2012). Challenges in the application of e-learning by secondary school teachers in Anambra State, Nigeria. African Journal of Teacher Education 2 (1), 1-15.

[35] Nwokike O. and Chiemeka I. P. (2011). Perceived readiness of teachers for online education in the University of Ibadan, Oyo state, Nigeria. Journal of Education and Practice 2 (7), 1-10. Retrieved Feb 1, 2016, from www.iiste.org.

[36] Nwokolo, S. A., Aliu, S. and Rabiu, G. M. (2017). A review of e-learning technologies adoption in Nigeria's tertiary education institutions. Journal of Engineering, Science and Technology 1 (1): 67-71.

[37] Ofuyatan O., Opaluwa, E. and Adeola, A. (2014). Challenges and effects of e-learning in the development of architecture and engineering in Nigeria's private tertiary institution. Developing Country Studies 4 (23), 130-134. Retrieved Feb 1, 2016, from www.iiste.org.

[38] Onwuagboke, B. B. C, Singh, T. K. R and Fook, F. S. (2015). Need for ICT integration for effective instructional delivery in Nigerian colleges of education. Journal of Education and Practice 6 (3), 51-56. Retrieved Feb 1, 2016, from www.iiste.org.

[39] Peeraer and Petegem, (2011). Factors influencing integration of ICT in higher education in Vietnam. Global Learn 2010. $\begin{array}{llll}\text { Retrieved Nov. 17, 2015, from } & \end{array}$ http://www.editlib.org/p/34284/.

[40] Sangra, A. and Gonzalz, S. (2010). The role of ICTs in improving teaching and learning processes in primary and secondary schools. ALT-Journal of Research in Learning $\begin{array}{llll}\text { Technology } & 18 & \text { (3), } & \text { 207-220. }\end{array}$ $10.1080 / 09687769.2010 .529108$

[41] Ubachs, G., Konings, L. and Brown, M. (eds). (2017). The Envisioning Report for Empowering Universities. Maastricht, NL: EADTU.

[42] Wineburg, S., McGrew, S., Breakstone, J. and Ortega, T. (2016). Evaluating information: The cornerstone of civil online reasoning. Stanford University, CA.: Stanford Digital Repository. Available at http://purl.stanford.edu/fv751yt5934 